Int. J. Dev. Biol. 62: 245-255 (2018)

https://doi.org/10.1387/ijdb.170322bp

\title{
Pluripotency in avian species
}

\author{
BERTRAND PAIN*, CLÉMENCE KRESS and SYLVIE RIVAL-GERVIER \\ Univ Lyon, Université Lyon 1, INSERM, INRA, Stem Cell and Brain Research Institute, U1208, USC1361, Bron, France
}

\begin{abstract}
Pluripotency defines the ability of a cell to self-renew and to differentiate into all embryonic lineages both in vitro and in vivo. This definition was first established mainly with the mouse model and the establishment of mouse embryonic stem cells (ESCs) in the 1980's and extended later on to other species including non-human primates and humans. Similarly, chicken ESCs were derived and established in vitro from pregastrulating embryos leading to cells with unique properties at molecular, epigenetic and developmental levels. By comparing the properties of murine, mammalian and avian ESCs and of the more recently discovered induced pluripotential stem (iPS)-derived cells generated in all of these species, avian specificities start to emerge including specific molecular genes, epigenetic mark profiles and original developmental properties. Here, we present common, but also avian-specific elements that contribute to defining avian pluripotency.
\end{abstract}

KEY WORDS: pluripotency, avian, embryo, chicken embryonic stem cell, markers

\section{The different states of pluripotency described in mammals}

Pluripotency is defined by the ability of a cell to self-renew and to differentiate into all of embryonic lineages both in vitro and in vivo. Different states of pluripotency have been described in rodents, including the naïve state and the primed state (Hackett and Surani, 2014; Smith and Nichols, 2009). Naïve pluripotency is captured in vitro from the epiblast of the pre-implantation embryo using either Leukemia Inhibitory Factor (LIF) and Bone Morphogenetic Protein (BMP) 4, or LIF alone associated with a cocktail of GSK3 and MEK inhibitors, designated the 2i/LIF condition (Ying et al., 2008, Nichols and Smith, 2009). Mouse embryonic stem cell (ESCs), first established in vitro in the early 80' from blastocysts (Evans and Kaufman, 1981; Martin, 1981) epitomize the naïve state of pluripotency, whereas the epiblast stem cells (EpiSCs) derived from the late epiblast of post-implantation mouse embryos (Brons et al., 2007; Tesar et al., 2007) epitomize the primed state of pluripotency (Fig. 1). Conversion of naive ESCs to primed EpiSCs can be easily achieved by switching culture conditions from 2i/LIF to FGF2/Activin A. Reversion of EpiSC to ESC is far more difficult and usually requires enforced expression of genes encoding naïve state-specific transcription factors such as KIf2, KIf4, Nanog, Stat3; NR5a1, NR5a2 (Illich et al., 2016; Hall et al., 2009; Zhou et al., 2010; Guo et al., 2010; 2009; Bao et al., 2009). The formative state, ant ansient state between naïve and primed states was recently described and characterized by an early ex- pression of Otx2, Sox3 and Oct6 (Acampora et al., 2013; 2016; Kalkan et al., 2017; Smith, 2017). Unlike the naïve and primed states, the formative state cannot be stabilized in a metastable state in culture. Finally, populations of mouse ESCs (i.e. naïve state) contain a rare sub-population (2-3\%) of cells with molecular and functional characteristics of the blastomeres of the 2-cell stage embryo, including the ability to transactivate the Murine ERV-L endogenous retrovirus. They are designated 2C cells (Hackett et al., 2017; Fujii et al., 2015; Macfarlan et al., 2012). Unlike ESCs that only contribute to embryonic tissues when injected into mouse pre-implantation embryos, $2 \mathrm{C}$ cells contribute to both embryonic and extra-embryonic tissues when assessed in the same experimental setting. This enlarged competency is sometimes referred to as plenipotency (Condic et al., 2014).

Defining features of the $2 \mathrm{C}$, naïve, formative and primed states include culture conditions, gene expression, and epigenetic marks (Marks et al., 2012; Los Angeles et al., 2015). Transcription factors Oct4 (Pou5f1), Sox2 and Nanog form the core pluripotency network, which sustain self-renewal of PSCs in the naïve, formative, and primed states. In mouse ESCs, additional transcription factors reinforce the core pluripotency network and support the naïve state of pluripotency in naïve ESCs (Kalkan et al., 2017; Dunn et al., 2014; Kim et al., 2009). 2C cells do not express Oct4, Nanog and Sox2. Instead, they express the 2 Cspecific genes Zscan4 and

Abbreviations used in this paper: EpiSC, epiblast stem cell; ERV, endogenous retroviruslike sequence; ESC, embryonic stem cell; MDV, Marek's disease virus.

\footnotetext{
*Address correspondence to: Bertrand Pain. Univ Lyon, Université Lyon 1, INSERM, INRA, Stem Cell and Brain Research Institute, U1208, USC1361, 69500, Bron, France. Tel.: +33 472913475. E-mail: Bertrand.pain@inserm.fr - (ID) http://orcid.org/0000-0002-1210-8444
} 
Tcstv1 (MacFarlan et al., 2012; Condic et al., 2014).

In non-rodent mammals (i.e. human and non human primates, rabbits, dogs, hamsters, and minks), in which ESCs have been derived and well characterized, defining the different states of pluripotency is still a challenge. In those species, different culture conditions were applied to derive pluripotent stem cells harboring characteristic features of either naïve or primed rodent ESCs (Boroviak and Nichols, 2017; Savatier et al., 2017; Ware, 2016; Guo et al., 2016; Chen et al., 2015; Gafni et al., 2013).

\section{The characteristics of early avian embryo development}

In birds, due to the telolecithe nature of the ovocyte, the first cleavages of the fertilized egg occur without complete segmentation of the yolk (Watt et al., 1993; Fabian and Eyal-Giladi, 1981). A description of the timing of development and cellularization process was hampered by the difficulty to collect well-staged embryos in the female tract. At oviposition, chick and quail embryos are at the late blastula stage (Eyal-Giladi \& Kovak stage $X$-EGK-X to EGK-XII). In contrast, turkey and duck embryos are at mid-blastula (EGK-VII) and zebrafinch embryos at the early blastula (EGK-VI), (Mak et al., 2015; Murray et al., 2013; Sellier et al., 2006; Bakst et al., 1997; Eyal Giladi and Kovak, 1976,). During the cellularization process in chicken, the two main lineages, epiblast and hypoblast, are rapidly individualized from the early EGK-II stage. Zygotic gene activation starts at EGK-III stage. Cells undergo rapid cell proliferation resulting in the formation of multiple cell layers at the late blastula stage (Sheng, 2014; Nagai et al., 2015). Expression profiles of SOX3, ENS1/ERNI, GATA4, GATA6, DAZL NANOG, POUV and a few other genes have been described in chicken and zebrafinch ovipositional embryos, which helped to characterize the early developmental stages (Jean et al., 2015; Mak et al., 2015; Nagai et al., 2015; Lee et al., 2015). The presence of pluripotent cells at late chicken blastula stage (EGK-X - EGK-XII) embryos was demonstrated after injecting dispersed blastodermal cells (BCs) into same stage recipient embryos to generate somatic and germline chimeras (Petitte et al., 1990, Carscience et al., 1993; Kino et al., 1997; Etches et al., 1997). These observations led to the establishment of chicken embryonic stem cells (cESCs) from the BCs using a culture medium supplemented with serum, LIF and FGF (Fig. 2) (Pain et al., 1996). Long-term cultured cESCs were unable to produce germline chimeras with a high efficiency (Pain et al., 1996; Petitte et al., 2004). However, in birds, germ cells originate from a germplasm and follow a preformation process of the germ lineage in contrast to the inductive mechanism that exists in mammals (Extravour and Akam, 2003). Detection of DAZL and CVHRNAs and proteins as early as the first cleavages supports an early segregation of germ cells from the soma (Tsunekawa et al., 2000; Lee et al., 2016; Mak et al., 2015). Moreover, the long term cultured primordial germ cells (PGCs) were also established from both circulating and gonadal germ cells, using culture conditions close to those originally used for the derivation of cESCs (Van de Lavoir et al., 2006; Choi et al., 2010; McDonald etal., 2010). Recent reports deciphering the signaling pathways presiding proliferation of long term cultured PGCs indicate that they are dependent on FGF2, insulin and Activin for long-term establishment (Whyte et al., 2015). Altogether, the early segregation of soma and germ lineages strongly suggests that CESCs and PGCs exhibit different molecular and developmental properties. Yet cESCs retain some plasticity for induction toward the germ lineage (Lavial et al., 2009).

In birds, the presence of putative plenipotent and pluripotent cells in the embryo before the EG-X stage has been hypothesized but, until now, only demonstrated in the zebrafinch. This demonstration is only based on the expression of pluripotency markers; the demonstration that zebrafinch ESCs can suportv long-term propagation and chimera formation is lacking (Mak et al., 2015).

\section{Control of pluripotent states by culture conditions}

In mice LIF is a key factor to drive self-renewal via activation of the LIFR/JAK/STAT3 signaling pathway. A similar activity appears to operate in cESCs, evidenced by phosphorylation of STAT3 after LIF induction (Horiuchi et al., 2004) and stimulation of self-renewal

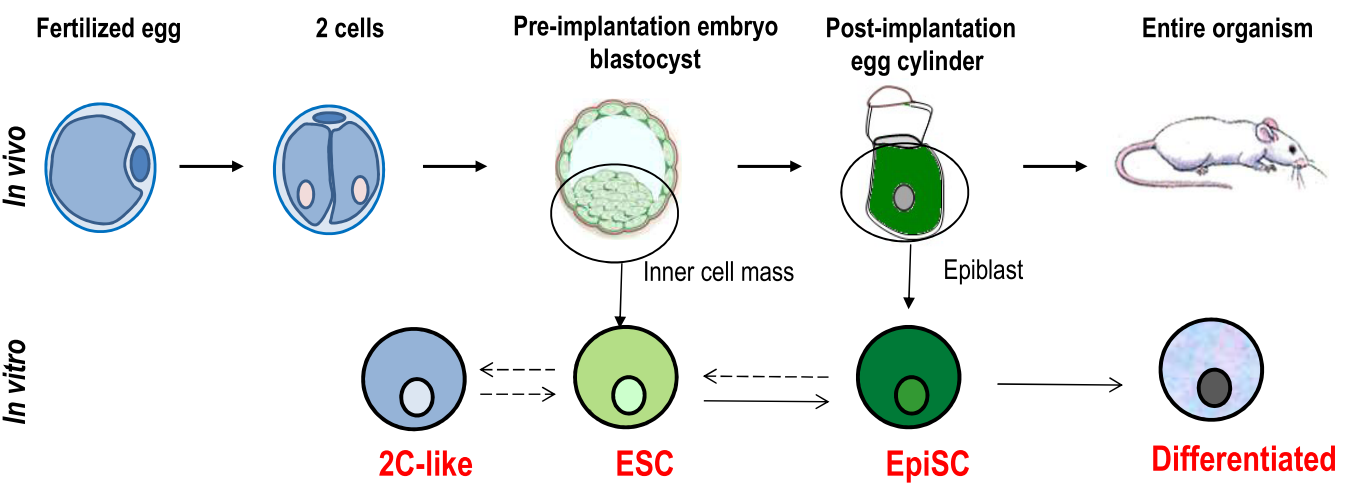
and proliferation induced by all GP130-related cytokines tested including IL6, IL-11, OSM and CNTF (Pain et al., 1996). In mice, stabilization of the naïve state of pluripotency is achieved using PD0325901 and CHIR99021, two

Fig. 1. Different states of pluripotency were defined in the mouse model. Different states of pluripotency have been described in rodents, including the naïve state and the primed state. Mouse embryonic Primed

Plenipotency

Naïve

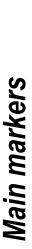

MuLTR

Zscan,

Tscf

Plu
Oct4, Nanog
Sox2,
Nrob1
Esrrb, Klf2,
Fgf4

Pluripotency


Oct4, Nanog

Sox2

Fgf5

Cripto stem cells (ESCS), first established in vitro in the early $80^{\prime}$ from blastocysts, epitomize the naive state of pluripotency, whereas the epiblast stem cells (EpiSCs) derived from the late epiblast of post-implantation mouse embryos epitomize the primed state of pluripotency. $2 \mathrm{C}$ cells are a rare sub-population of mouse pluripotent ESCs with molecular and functional characteristics of the blastomeres of the 2cell stage embryo. Each state is characterized by specific gene markers and developmental properties. 


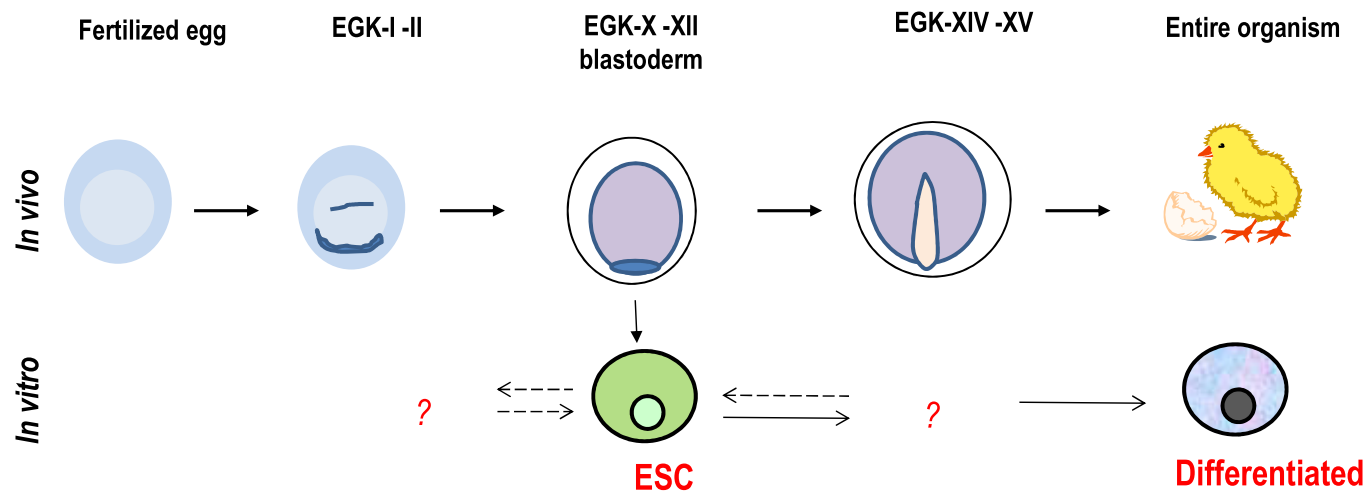

Pluripotency

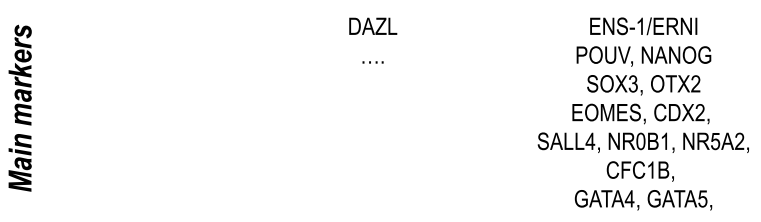

pharmacological inhibitors of mitogen activated protein kinase kinase (MAP2K) and glycogen synthase kinase 3 (GSK3), respectively (so-called 2i/LIF condition). (Ying et al., 2008; Nichols et al., 2009). In birds, established cESCs cannot be propagated in $2 \mathrm{i} / \mathrm{LIF}$ condition due to high toxicity of the GSK3 inhibitor (unpublished data). In the zebrafinch, MEK inhibitor seems to exert a positive effect on isolated BCs collected at the oviposition stage (EG-VIII), evidenced by the elevated expression of FBXO15, a marker of naïve pluripotency in mice (Mak et al., 2015). In human and nonhuman primates, strategies were elaborated to reprogram ESC and induced pluripotent stem cells (iPSC) to naïve-like pluripotency. These studies make use of cocktails of kinase inhibitors, including inhibitors of MEK and GSK3 $\beta$ (Chen et al., 2015), MEK, GSK3 $\beta$ and FGFR (Takashima et al., 2014) and MEK, GSK3 $\beta$, BRAF, JNK, ROCK and SRC (Gafni et al., 2013; Theunissen et al., 2014) The resulting cells exhibit many of the characteristic features of mouse naïve ESCs at both genetic and epigenetic levels. They have been extensively compared and their properties discussed (Theunissen et al., 2016; Savatier et al., 2017). The effect of the aforementioned small molecules on the growth and pluripotency of avian ESCs has not been reported.

\section{Hallmarks of avian pluripotency}

The cardinal features of ESCs include alkaline phosphatase and telomerase activities, expression of specific cell surface antigens, transcription factors, and Endogenous retroviral elements (ERVs), a deregulated cell cycle, an unsual epigenetic landscape at both DNA and histone level, differentiation capacities, and chimeric competency.

\section{Immunocytological profile}

Rodent ESCs have been extensively characterized using specific monoclonal antibodies originally raised against Embryonic Carcinoma (EC) cells. These antibodies are able to discriminate the original 'undifferentiated' state of these cells before induction
SOX2

Fig. 2. Pluripotency in avian species. The presence of pluripotent cells in late chicken blastula stage (EGK-X - EGK-XII) embryos was demonstrated after injecting dispersed blastodermal cells (BCs) into same stage recipientembryos to generate somatic and germline chimeras. These observations led to the establishment of chicken embryonic stem cells (cESCs) from the BCs. cESCs were characterized at the molecular level. No otherpluripotent states have been reported yet in the avian species. of differentiation. In particular, antibodies from the Stage Specific Embryonic Antigen (SSEA) family, which recognize specific rearrangements of glycosylated proteins, have proved relevant tools for discriminating undifferentiated and differentiated cells (Solter and Knowles, 1978; Kannagi et al., 1983), as well as for identifying ESCs in primates (Thomson et al., 1996; 1998). These antibodies have also been used to characterize ESCs and germ cells in non-mammalian species, including birds (Pain et al., 1996; Lavial and Pain, 2010; McDonald et al., 2010), fishes (Panda et al., 2011, Sasado et al., 1999), and anuran frogs (Yoshida-Noro et al., 2010). Typically, cESC are positive for SSEA-1, SSEA-2, SSEA-3 antigens, a well as for another antigen designated EMA-1 raised against mouse EC cells (Urven et al., 1988; Hahnel and Eddy, 1983). In contrast, they are negative for SSEA-4, a marker of human and non human primate ESCs (Lavial and Pain, 2010) (Fig. 3).

\section{Cell cycle distribution}

One of the most striking feature of mouse naïve ESCs is their ability to proliferate very rapidly with a doubling time of 8 to $10 \mathrm{~h}$. In contrast, human and chicken ESCs exhibit a doubling time of 18-20h and 16-18h, respectively. A few lines derived from local breeds exhibit a slower rate (Jean et al., 2013). Mouse ESCs have a distorded cell cycle distribution with approximately $20 \%$ in G1, $70 \%$ of the cells in S phase, and $10 \%$ in G2/M phase. This is in contrast to mouse embryonic fibroblasts showing approximately $80 \%, 10 \%$ and $10 \%$ of the cells in the G1, S, and G2/M phases, respectively. In contrast, cESCs have $40 \%$ of cells in G1 phase, $40 \%$ in S phase, and $20 \%$ in G2/M as compared to chicken embryonic fibroblasts (CEF) showing $60 \%, 10 \%$, and $30 \%$ of the cells in G1, S, and G2/M phases, respectively. These data suggest that $\mathrm{cESC}$ also exhibit a distorded cell cycle distribution in line with the mouse data. No information regarding the expressing of cell cycle regulators (i.e. phosphorylation status of RB, expression of cyclins and cyclin:Cdk complexes) is available in cESCs (Coronado et al., 2013; Jirmanova et al., 2002). 


\section{Molecular profile}

At the oviposition stage, chicken embryos contain 30,000 to 40,000 cells forming epiblast and hypoblast. Only bulk analysis of the transcriptome of blastodermal cells, cESCs, and PGCs are available, confirmed by in situ hybridizations for a few pluripotency factors. In mice and Humans, several signaling pathways operate on ESC to regulate the balance between self-renewal and differentiation. A network of transcription factors (TF) is involved in the establishment and maintenance of pluripotency. At the top of the list, Oct4, Sox2 and Nanog form the core pluripotency network, which regulates pluripotency by integrating positive and negative signals to repress commitment into differentiation. As mentioned earlier, some mouse genes are used as markers to discriminate the naïve and primed states of pluripotency. In avian species, the molecular characterization of cESCs and of early stage EGK$X$ embryos has led to the identification of components of the pluripotency-associated gene network previously described in mice and other mammals (Hwang et al., 2016; Jean et al., 2015; Mak et al., 2015; Bertocchini and Stern, 2012; Lavial et al., 2007). However, the function of the avian homologs of mammalian pluripotency regulators in avian stem cell pluripotency remains poorly described. Only the function of POUV, NANOG and LIFR/JAK/ STAT signaling pathway in avian pluripotency has been examined (Nakanoh et al., 2017; Lavial et al., 2007). The Oct4 (Pou5f1) gene, one of the most important regulator of pluripotency in mammals is absent from the avian genome. In contrast, POUV, characterized as the ortholog of the mammalian POU5F3 gene seems to exert an OCT4-like function in avian pluriptotency (Frankenberg et al., 2014; Frankenberg, 2015; Lavial et al., 2007). The NANOG gene is also playing a key role in the maintenance of avian pluripotency and is expressed in early embryos, cESC and PGCs (Nakanoh et al., 2015; 2017; Shin et al., 2011; Lavial et al., 2007; Canon et al., 2006). Chicken early embryos express the SOX3 gene at

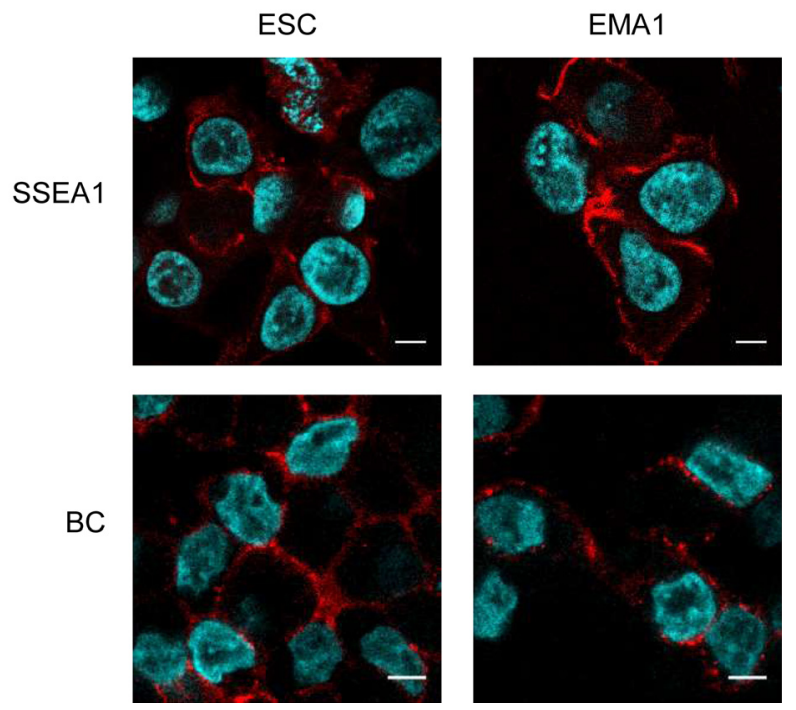

Fig. 3. Chicken embryonic stem cells (cESCs) are specifically recognized by the pluripotency-specific antibodies SSEA1 and EMA1. CESCS were cultured and blastodermal cells (BC) were observed in stageX-XII embryos. Immunodetection of SSEA1 and EMA1 markers (red) were performed as described (Fuetetal., in preparation). DNA was counterstained byTOPRO-3. Single confocal images are shown. Scale bar, 5 um. a high level, whereas cESCs express SOX2. Intriguingly, SOX2 is only expressed in the neural plate of the developing chicken embryo (Roellig et al., 2017; Iwafuchi-doi et al., 2011; Rex et al., 1997), suggesting an artefactual activation of SOX2 during cESC establishment in vitro. Unlike SOX2, SOX3 is only detected during early embryonic stages by in situ hybridization and transcriptomic analyses (Jean et al., 2015). Other naïve pluripotency-associated genes defined in mice, including SALL4, LIN28, DNMT3A, DNMT3B, NR0B1 and NR5A2, are also expressed in BCs, PGCs and cESC (Jean et al., 2015; Rengaraj et al., 2011). In contrast, the mouse naïve transcription factors TBX3 and KLF2 are not expressed in any of them (Dan et al., 2013; Antin et al., 2010). Additionally, until now REX1 (ZPF42) and UTF1 have not been found in the avian genome. Therefore, genes expressed in undifferentiated, long-term proliferating $c E S C s$ include SOX3, POUV (POU5F3), DNMT3B, EPCAM, CLDN1, VGLL2, EOMES, CFC1B, GATA5, NANOG, ESRP2, OTX2, TRIM71, GATA4, FOXA2, LIN28A, ASTL, ENS-1, CDH1 and SALL4 (Jean et al., 2015; Vautherot et al., 2017; Acloque et al., 2012; unpublished data). These genes encode transcription factors, DNA demethylases, and cell adhesion molecules. It should be noted that, except for POUV and NANOG (Lavial et al., 2007), evidence that these genes exert the same function in avian stem cells as in mammalian stem cells is lacking.

\section{ERVs as markers of the different pluripotency states}

Endogenous retrovirus-like sequences (ERVs) are fossils of ancient retroviral integration into animal genomes. They represent up to $10 \%$ of mammalian genomes, 80 to $90 \%$ of plant genomes, but only $1.6 \%$ to $3 \%$ of the chicken genome as estimated by the Gal4 genome assembly (Jurka et al., 2005; Mason et al., 2016). However, it remains unclear if this deficit in LTR retrotransposon-derived elements is biologically accurate or due to technical limitations in their annotation. Among these LTR retrotransposons, some of them are structurally intact. Transcription is rare, and most of the time is fragmented or does not code for functional proteins. Nevertheless, the identification of viral transcripts, the expression of co-opted genes such as gamma-retrovirus-derived Ovex1 gene, and the presence of a large number of intact LTRs stimulated the exploration of their function (Carré-Eusèbe et al., 2009). There is a growing body of evidence that ERVs are tightly regulated in pluripotent cells and participate in the regulation of mammalian development, suggesting that ERV expression has undergone positive selection during evolution (Rowe et al., 2010). As a matter of fact, even if most ERVs are no longer capable of complete transcription and/ or retrotransposition, some of them possess functional regulatory sequences that target their transcriptions at specific developmental stages and/or in specific tissues. Interestingly, it has been shown that ERV transcription is tightly regulated during the early steps of mouse development (Evsikov et al., 2004; Peaston et al., 2004; Solter et al., 2004). This is the case of MuERV-L, of which $25 \%$ of the approximately 700 copies are transcribed during a narrow window of development encompassing embryonic genome activation. MuERV-L is fully silenced by the morula stage (MacFarlan et al., 2012). The MuERV-L promoters (Mt2_mm) produce chimeric transcripts with 307 cellular genes, suggesting that they regulate the transcriptional activity of mouse genes. In chicken, c-ENS-1 (also called $c E R N I$ ) is a member of the large Soprano family identified by gene trap. It is strongly expressed in early chicken embryo and cESCs. Expression of the cENS-1 gene dramatically 
decreases at the onset of cESC differentiation and its promoter activity is reduced by two-fold after treatment of $\mathrm{CESC}$ with retinoic acid. c-ENS1 gene is strongly expressed in the epiblast prior to gastrulation and during neural plate induction (Streit et al., 2000; Acloque et al., 2001, Lerat et al., 2007). Its expression is controlled by CP2 and NANOG, two transcription factors of the core pluripotency network, and by GATA4 and ETS, two transcription factors required for extraembryonic endoderm differentiation (Mey et al., 2012; Acloque et al., 2004). It has been suggested that c-ENS1 functions as a repressor of SOX2 promoter through its interaction with Geminin and HP1 $\gamma$ during early gastrulation. When the cells are assigned to a neural plate fate, they produce BERT protein, which destabilizes cENS1/Gemini/HP1 $\gamma$ complex (Papayonotou et al., 2008). The role of BERT and its regulation in cESCs remain unclear. Its cytoplasmic and nuclear localization is differentially regulated upon differentiation (Blanc et al., 2014) showing that its regulation in pluripotent cells is more complex than expected and could play a role in the regulation of chicken pluripotency.

\section{Epigenetic landscape}

The extensive characterization of mouse ESC has uncovered several epigenetic mechanisms involved in the establishment and maintenance of pluripotency (Orkin et al., 2011, Tollervey et al., 2012). Epigenetic features related to chromatin can be observed both at the level of individual gene transcription control and at the level of chromatin organization in the nucleus. Promoters and enhancers of pluripotency genes remain free of epigenetic repressive marks, which will be only written at the onset of differentiation (Pedersen et al., 2016. Petell et al., 2016). In contrast, the promoters of developmentally-regulated genes are inactivated by histone post-translational modifications (PTM) such as trimethylation of $\mathrm{H} 3$ lysine 27 (H3K27me3), and yet they are kept poised for transcriptional activation by the presence of trimethylation of lysine 4 (H3K4me3). This peculiar chromatin conformation is designated "bivalent domains", and it is regulated by Polycomb and Trithorax group proteins (Voigt et al., 2013). Moreover, pluripotent cells display a unique higher-order organization of their genome, which is shaped by pluripotency factors

A

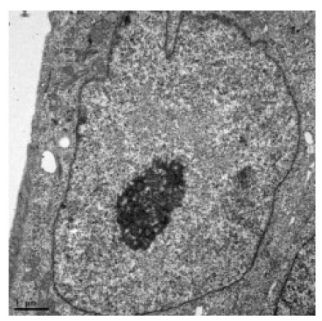

B

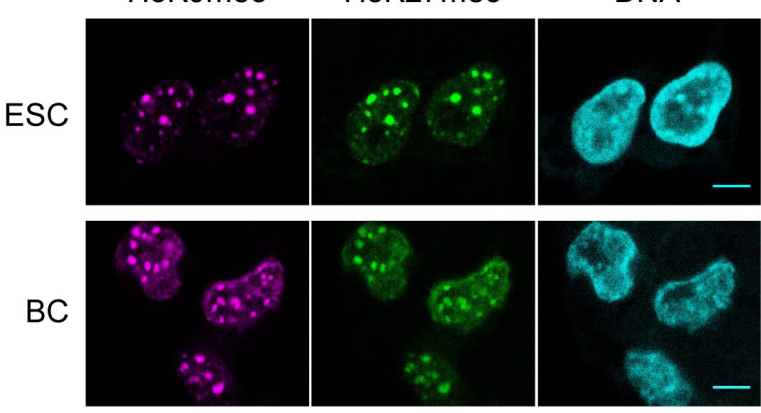

C

H3K9me2

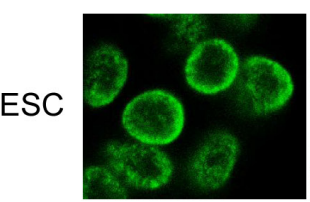

$\mathrm{BC}$

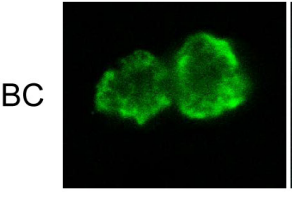

$\mathbf{E}$

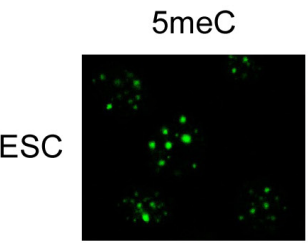

DNA

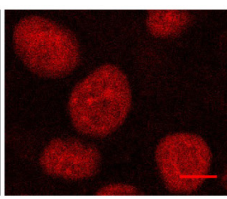

$\mathrm{BC}$

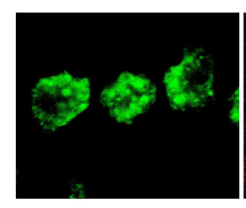

DNA
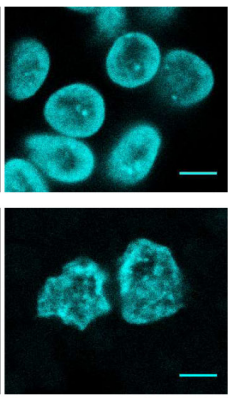

D

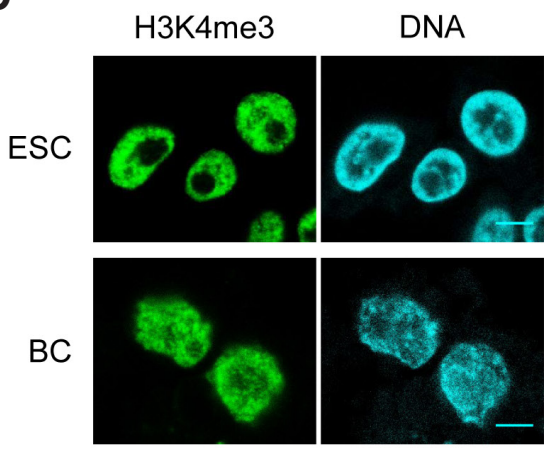

$\mathbf{F}$

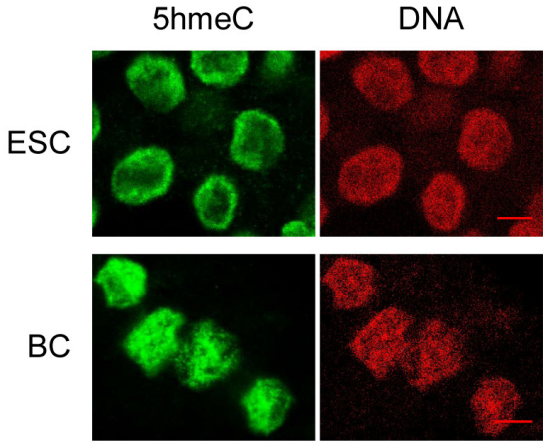

(Denholtz et al., 2013, de Wit et al., 2013). The abundance of poised genes and the hyperdynamicity of chromatin proteins in the nucleus would result in a globally more open epigenetic state in pluripotent than in committed or differentiated cells (Meshorer et al., 2006). This open chromatin conformation is believed to provide mouse ES cells with a high plasticity for chromatin-related gene regulation mechanisms, enabling rapid integration of gene expression changes upon differentiation signals (Mattout et al., 2010).

Few of the epigenetic modifications possibly involved in the maintenance of pluripotency have been investigated in avian ESC. Pluripotency gene expression control is likely to rely on similar mechanisms in chicken and mammals.

Fig. 4. Pluripotent avian cells exhibit epigenetic marks, some shared with their mammalian counterparts, some more specific. Chicken embryonic stem cells (ESC) were cultured and blastodermal cells $(B C)$ were observed in tissue sections from stage $X-X I I$ embryos. Immunodetection of histone and DNA modifications were performed as described (Kress et al., 2016). (A) Transmission electron micrograph of a cESC nucleus. Scale bar, 1 $\mu \mathrm{m}$. (B) Co-immunodetection of H3K9me3 and H3K27me2/3. (C) Immunodetection of H3K9me2. (D) Immunodetection of H3K4me3. (E) Immunodetection of 5-methylcytosine. (F) Immunodetection of 5-hydroxymethylcytosine. DNA was counterstained by TO-PRO-3, except in (EF) were propidium iodide was used. Single confocal images of representative nucle are shown. Scale bar, $5 \mu \mathrm{m}$. 
In particular, a low DNA methylation and a high acetylation of lysine 9 on $\mathrm{H} 3$ are important to keep pluripotency genes NANOG and POUV (POU5F3) active in CESC and EG cells (Wang et al., 2016, Jiao et al., 2013). DNA methylation and hydroxymethylation, histone PTM such as lysine methylation or acetylation and the Polycomb and Trithorax protein complexes, which have been extensively described in mouse ESC (Orkin et al., 2011) are also likely involved in the control of the balance of expression between pluripotency and differentiation-. Indeed, most genes coding for modifiers of chromatin or DNA are expressed in CESC and BC (Jean et al., 2015; Kress et al., 2016). Notably, the DNA methyltransferase genes DNMT3A and B, but not DNMT1, are strongly expressed in pluripotent cells compared to differentiated cells. The genes encoding TET1 and TET3 enzymes, which catalyze the conversion of $5 \mathrm{mC}$ to $5 \mathrm{hmC}$, are also strongly expressed. The expression levels of chromatin remodeling factors including BRG1/SMARCA4, HELLS/SMARCA6, SMARCC1, and SMARCD1, of histone acetylases and deacetylases including GCN5/KAT2A, HDAC1, and HDAC2, are higher in pluripotent cells as compared to diferentiated cells. Genes encoding histone methyltransferases and demethylases, Polycomb, and Trithorax genes are expressed
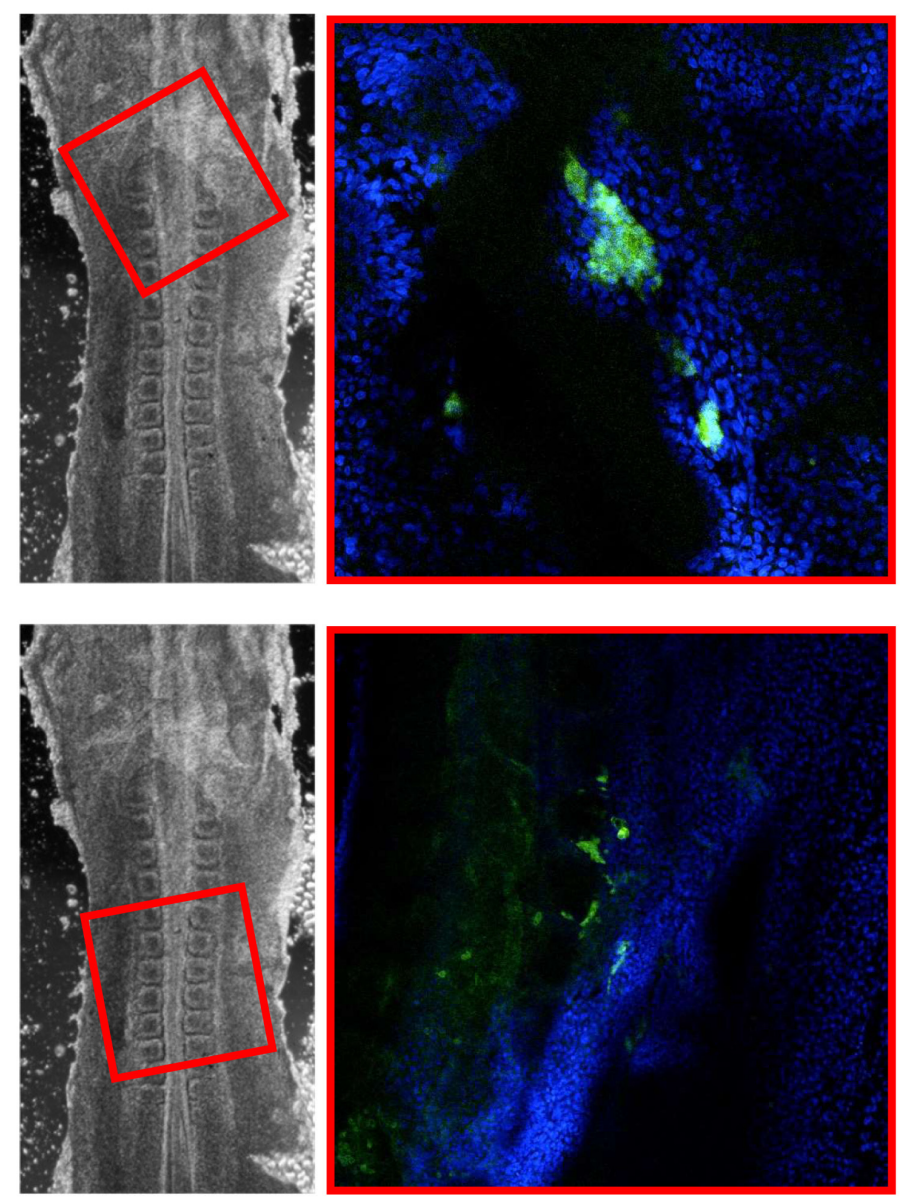

Fig. 5. Established chick embryonic stem cells (cESC) are able to contribute to chimeras. Long term proliferating CESCS were GFP-labeled with a lentiviral vector and injected into EGK-X-XII stage embryos as previously described (Aubel and Pain, 2013). A HH10 stage embryo presenting GFP cells (green) inserted in different areas of somatic tissue is shown. Nuclei were stained with Hoechst (b/ue). at various levels in BCs and cESC.

Chromatin modifiers are active in pluripotent chicken cells, as shown by the presence and distribution of DNA methylation and various histone PTM in the nuclei of cESC and BC compared to differentiated cells (Kress et al., 2016). However, some of the chromatin features specific to mESC are not found in cESC, and reciprocally, pluripotent chicken cells have specific features not observed in mESC. In mESC, the majority of the chromatin appears homogenous and decondensed in the nucleus of pluripotent cells, and it becomes heterogeneous in appearance with distinct heterochromatin domains after differentiation (Fussner et al., 2011). At the cytological level, cESC display few prominent heterochromatin compartments (Fig. 4A). Whereas H3K9me3 and heterochromatin Protein $1 \gamma$ are enriched in diffuse regions in mESCs (Meshorer et al., 2006), large and well-defined H3K9me3-containing domains similar to those described in differentiated cells are already present in cESC and BC (Fig. 4B and Kress et al., 2016). Notably, these domains include pericentric heterochromatin $(\mathrm{PCH})$, which embeds DNA repeats of centromeres and pericentromeres of multicellular eucaryotes and forms the cytologically distinct chromocentres (Kress et al., 2016). In chicken cells, the observable chromocenters correspond mostly to the PCH of microchromosomes (Maslova et al., 2015). The distribution of most histones PTM in pluripotent chicken cells is similar to what is observed in mammalian cells; the repression-associated $\mathrm{H} 3 \mathrm{~K} 9 \mathrm{me} 2$ tends to be localized in DNAdense regions at the nuclear periphery, but not at chromocenters; active marks such as H3K9ac and H3K4me3 form numerous foci in euchromatic regions of the nucleus (Fig. 4 C-D and Kress et al., 2016).

Trimethylation of H3K27, the common mark of facultative heterochromatin, shows a striking difference between mammalian and avian ESCs. In cESCs, H3K27me3 is essentially detected at $\mathrm{PCH}$, whereas it is scattered in numerous small foci in mESCs (Fig. 4B). The presence of H3K27me3, together with H3K9me3, at $\mathrm{PCH}$ is also observed in $\mathrm{BC}$ nuclei in both chicken and duck embryo (Kress et al., 2016 and unpublished data). After differentiation, the distribution of H3K27me3 marks gradually shifts to a mESC-like pattern (Kress et al., 2016 and unpublished data). The distribution of $\mathrm{H} 3 \mathrm{~K} 27 \mathrm{me} 3$ marks at $\mathrm{PCH}$ was recently confirmed as a marker of pluripotency in avian ESCs because chicken and duck fibroblasts gain it when reprogrammed to iPS cells (Fuet et al., 2017; Fuet et al., in preparation). In chicken, global levels of DNA methylation and hydroxymethylation are similar in pluripotent cells and differentiated cells. as well as their nuclear distributions in heterochromatin and euchromatin compartments respectively (Fig. 4 E-F and Kress et al., 2016).

Taken as a whole, epigenetic chromatin modifications of avian pluripotent cells are not strikingly different from those of mouse cells except the facultative heterochromatin mark H3K27me3, which co-localizes with constitutive heterochromatin. It is to be noted that cESC are representative of pluripotent cells of the embryo as they maintain patterns of chromatin and DNA modifications typical of $\mathrm{BC}$ even after prolonged culture.

\section{Differentiation of avian pluripotent stem cells}

Pluripotent stem cells are able to give rise to a differentiated progeny representative of all of the embryonic germ layers, ectoderm, mesoderm and endoderm. In vivo, once injected into host 
A

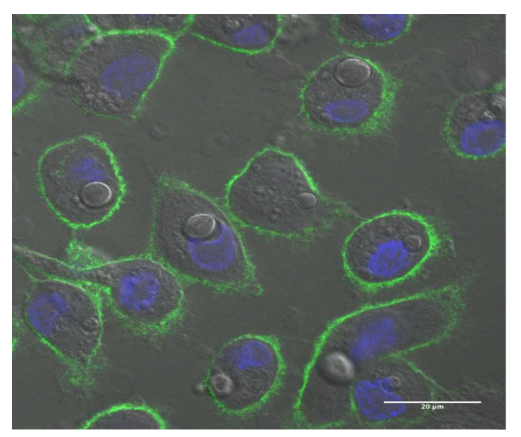

B
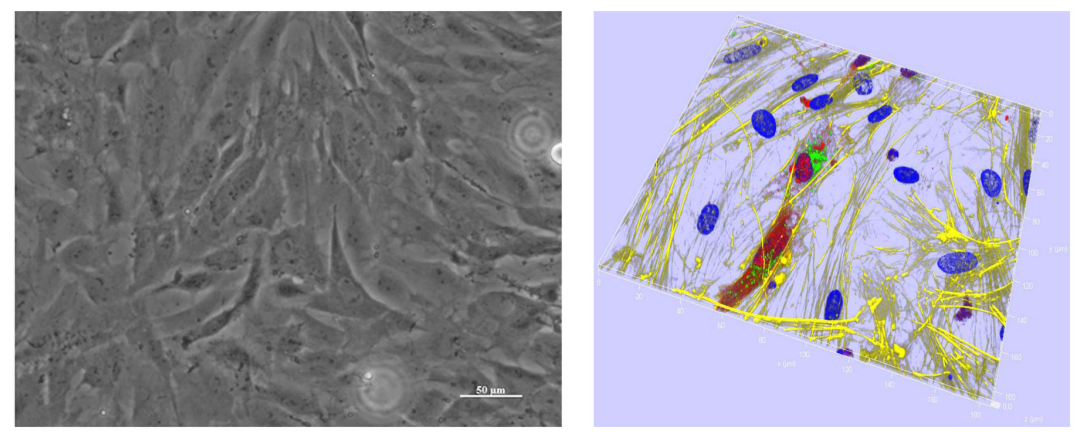

Fig. 6. Chicken embryonic stem cells (cESCs) can be differentiated toward various cell types and provide support for viral replication. (A) CESC were induced into differentiation and provided long-term proliferating keratinocytes as described (Couteaudier et al., 2015). The differentiated cells presented involucrin expression associated with keratinocyte commitment (green) and intracytoplasmic lipid droplets (arrow). Nuclei were stained with Hoechst 33342 (blue). (B) cESCs were induced into mesenchymal cells as described (Vautherot et al., 2017). They displayed a mesenchymal cell morphology with numerous stress fibers (yellow). They were able to replicate Marek's disease virus (MDV) as shown by the spreading of the recombinant labelled virus (red) with the gl glycoprotein (green). Nuclei were stained with DAPI (blue). embryos, cESCs are able to participate in the formation of all the somatic tissues and product chimeric embryos. The rate of chimerism can vary considerably from one chimera to the other. However, germ line colonization is very rare (Fig. 5) (Pain et al., 1996; Petitte et al., 2004; Van de Lavoir et al., 2006). In vitro, different protocols have been described to generate differentiated cells with specific phenotypes and properties. Typically, cESCs are induced to differentiate by the formation of embryoid bodies (EBs) in non-adherent culture plates. EBs are subsequently replated onto adherent plates in a culture medium supplemented with various differentiation inducers (Pain et al., 1996; Aubel and Pain, 2013). Differentiation can also be induced from a monolayer of adherent cESC using various cytokines and growth factors. As an example, mesoderm derivatives were obtained by treating cESCs with $\beta$-glycerophosphate and ascorbic acid, whereas treatment with WNT3A and ACTIVIN A induced endoderm differentiation (Boast and Stern, 2013). The combination of stromal cell-derived inducing activity (SDIA) (Kawasaki etal., 2000), BMP4 and ascorbic acid gave rise to long-term proliferating keratinocytes (Fig. 6A) (Couteaudier et al., 2015). Hexamethylene bis acetamide (HMBA) during SDIA induction was also used to derive the ESCDL-1 mesenchymal cell line (Fig. 6B) (Vautherot et al., 2017).

Avian ESC and their in vitro derivatives have the ability to replicate several types of viruses, which offers biotechnology and industrial applications. Duck EB66 ${ }^{\circledR}$ is one of the most promising avian cell line for this purpose. Unlike other cell lines (i.e. AGE1. $\mathrm{CR} \circledast$ and DuckCelt $\left.{ }^{\circledR}-\mathrm{T} 17\right)$, it was derived without any immortalizing agent (Leon et al., 2016; Jordan et al., 2009; Jordan et al., 2016; Petiot et al., 2017) and it can replicate a large spectrum of viruses. However, not all virus families could be successfully replicated with undifferentiated avian ESCs (Leon et al., 2016; Naruse et al., 2015). A few virus families require differentiated cells such as Mardiviruses that can be replicated on keratinocytes and ESCDL-1 mesenchymal cells (Fig. 6C) (Couteaudier et al., 2016, Vautherot et al., 2017).

\section{Re-capturing avian pluripotency in vitro}

Somatic cell reprogramming can be used to generate induced pluripotent stem (iPS) cells. Reprogramming is commonly achieved by overexpressing four transcription factors, Oct4, Sox2, Klf4 and c-Myc (referred to as the OSKM cocktail) (Takahashi and Yamanaka, 2006; 2016; Karagiannis and Eto, 2016). Other gene combinations have been used, such as the OSNL cocktail (Oct4, Sox2, Nanog and Lin28) (Yu et al., 2007). Other genes and molecules were shown to increase the efficiency of somatic cell reprogramming in mice and Humans (Stadtfeld and Hochedlinger, 2010). Somatic cell reprogramming appears to be far more difficult to achieve in non-mammalian species. Few studies, using human and mouse transcription factors as reprogramming genes reported the derivation and characterization of iPS-like cells in chicken (designated ciPS cells) (Choi et al., 2016; Yu et al., 2014; Lu et al., 2015;2012; Rosselo et al., 2013). By using chicken genes, iPS-like cells were also generated. In these studies NANOG was essential, in addition to the canonical OSKM gene combination, to achieve long term proliferating ciPS-like cells (Fuet et al., 2017; Katayama et al., 2017). ciPS cells exhibit markers of cESCs demonstrating reprogramming. However, there are not fully reprogrammed, as they still express some of the transgenes. Moreover, they seem to be impaired in their differentiation potential, suggesting abnormal reprogramming (Fuet et al., in preparation).

\section{Conclusions}

The exploration of avian pluripotency is still in its infancy. Cell puripotency can be demonstrated in vivo by the production of somatic and germline chimeras using cells isolated from pregastrulating embryos. Pluripotency is also evidenced in vitro by the long-term propagation of avian ESCs in culture, with properties very similar to those described in mammals. In chicken, pluripotent cells are present at the EGK-X-XII blastula stage. However, we lack a comparison with cells derived from EGK-VII early blastula as reported in the zebrafinch embryo. From the molecular point of view, in vitro cESCs exhibit an epigenetic profile similar to that of BCs cells. They also display a gene expression profile characterized by the expression of the cardinal regulators of pluripotency POUV (POU5F3), NANOG and SOX2, by the expression of naïve 
pluripotency-specific genes SALL4, LIN28, DNMT3A, DNMT3B, NR0B1 and NR5A2, and by the expression of primed pluripotencyspecific genes including EOMES, CFC1B, GATA5, OTX2, GATA4 and CDX2. A mixed naïve/primed expression profile could reflect either cell heterogeneity within the population of cESCs, or a gene expression profile intrinsic to avian pluripotency, or both. It is very important to bear in mind that markers of naïve and primed pluripotency have only been defined in rodents. Thus, it is still a speculation to conclude on the existence of naive and primed states of pluripotency in avian species. If various states of pluripotency do exist in birds, they are likely to diverge from the naïve and primed states described in mice both in molecular markers and underlying mechanisms.

cESCs are able to contribute to somatic tissues and produce embryonic and adult chimeras when injected into recipient embryos. In contrast, germ line contribution is still a rare event, which might be explained by the bird-specific mechanism of germ lineage segregation.

\section{Acknowledgments}

Thanks to JF Vautherot for providing illustrations and to $P$ Savatier for critics and comments. This work was supported by research grants from Agence Nationale de la Recherche, the ANRAviRepro ( $\left.N^{\circ} 09-B L A N-0141\right)$, ECLAIRE ( $N^{\circ}$ ANR-14-CE16-0002), and the Infrastructure Nationale en Biologie et Santé CRB-ANIM ( $n^{\circ}$ ANR-11-INBS-0003).

\section{References}

ACAMPORA D, DI GIOVANNANTONIO LG, SIMEONE A. (2013). Otx2 is an intrinsic determinant of the embryonic stem cell state and is required for transition to a stable epiblast stem cell condition. Development. 140: 43-55.

ACAMPORAD, OMODEI D, PETROSINO G, GAROFALO 4, SAVARESE M, NIGRO V, DI GIOVANNANTONIO LG, MERCADANTE V, SIMEONE A. (2016). Loss of the Otx2-Binding Site in the Nanog Promoter Affects the Integrity of Embryonic Stem Cell Subtypes and Specification of Inner Cell Mass-Derived Epiblast. Cell Rep. 15: 2651-2664.

ACLOQUE H, LAVIAL F, PAIN B. (2012). Astacin-like metallo-endopeptidase is dynamically expressed in embryonic stem cells and embryonic epithelium during morphogenesis. Dev Dyn. 241: 574-582.

ACLOQUE H, MEY A, BIROT AM, GRUFFAT H, PAIN B, SAMARUT J. (2004). Transcription factor CCP2 controls gene expression in chicken embryonic stem cells. Nucleic Acids Res. 32: 2259-2271.

ACLOQUE H, RISSON V, BIROT AM, KUNITA R, PAIN B, SAMARUT J. (2001). Identification of a new gene family specifically expressed in chicken embryonic stem cells and early embryo. Mech Dev. 103: 79-91.

ANTIN PB, PIER M, SESEPASARA T, YATSKIEVYCH TA, DARNELL DK. (2010). Embryonic expression of the chicken Krüppel-like (KLF) transcription factor gene family. Dev Dyn. 239: 1879-1887.

AUBEL P, PAIN B. (2013). Chicken embryonic stem cells: establishment and characterization. Methods Mol Biol. 1074: 137-150.

BAKSTMR, GUPTASK, AKUFFO V. (1997). Comparative development of the turkey and chicken embryo from cleavage through hypoblast formation. Poult Sci. 76: 83-90.

BAO S, TANG F, LI X, HAYASHI K, GILLICH A, LAO K, SURANI MA. (2009). Epigenetic reversion of post-implantation epiblast to pluripotent embryonic stem cells. Nature. 461: 1292-1295.

BERTOCCHINI F, STERN CD. (2012). Gata2 provides an early anterior bias and uncovers a global positioning system for polarity in the amniote embryo. Development. 139: 4232-4238.

BLANC S, RUGGIERO F, BIROTAM, ACLOQUE H, DÉCIMO D, LERATE, OHLMANN T, SAMARUT J, MEY A. (2014). Subcellular localization of ENS-1/ERNI in chick embryonic stem cells. PLoS One. 9: e92039.

BOAST S, STERN CD. (2013). Simple methods for generating neural, bone and endodermal cell types from chick embryonic stem cells. Stem Cell Res. 10: 20-28.
BOROVIAK T, NICHOLS J. (2017). Primate embryogenesis predicts the hallmarks of human naïve pluripotency. Development. 144: 175-186.

BRONS IG, SMITHERS LE, TROTTER MW, RUGG-GUNN P, SUN B, CHUVA DE SOUSA LOPES SM, HOWLETT SK, CLARKSON A, AHRLUND-RICHTER L, PEDERSEN RA, VALLIER L. (2007). Derivation of pluripotent epiblast stem cells from mammalian embryos. Nature. 448: 191-195.

CAÑÓN S, HERRANZ C, MANZANARES M. (2006). Germ cell restricted expression of chick Nanog. Dev Dyn. 235: 2889-2894.

CARRÉ-EUSĖBE D, COUDOUEL N, MAGRE S. (2009). OVEX1, a novel chicken endogenous retrovirus with sex-specific and left-right asymmetrical expression in gonads. Retrovirology. 6: 59

CARSIENCE RS, CLARK ME, VERRINDER GIBBINS AM, ETCHES RJ. (1993) Germline chimeric chickens from dispersed donor blastodermal cells and compromised recipient embryos. Development. 117: 669-675.

CHEN H, AKSOY I, GONNOT F, OSTEIL P, AUBRY M, HAMELA C, ROGNARD C, HOCHARD A, VOISIN S, FONTAINE E, MURE M, AFANASSIEFF M, CLEROUX E, GUIBERTS, CHEN J, VALLOTC, ACLOQUE H, GENTHON C, DONNADIEU C, DE VOS J, SANLAVILLED, GUÉRIN JF, WEBERM, STANTON LW, ROUGEULLE C, PAIN B, BOURILLOT PY, SAVATIER P. (2015). Reinforcement of STAT3 activity reprogrammes human embryonic stem cells to naive-like pluripotency. Nat Commun. 6: 7095.

CHOI HW, KIM JS, CHOI S, JU HONG Y, BYUN SJ, SEO HG, DO JT. (2016). Mitochondrial Remodeling in Chicken Induced Pluripotent Stem-Like Cells. Stem Cells Dev. 25: 472-476.

CHOI JW, KIM S, KIM TM, KIM YM, SEO HW, PARK TS, JEONG JW, SONG G HAN JY. (2010). Basic fibroblast growth factor activates MEK/ERK cell signaling pathway and stimulates the proliferation of chicken primordial germ cells. PLOS One. 5: e12968.

CONDIC ML. (2014). Totipotency: what it is and what it is not. Stem Cells Dev. 23: 796-812.

CORONADO D, GODET M, BOURILLOT PY, TAPPONNIER Y, BERNAT A, PETIT M, AFANASSIEFF M, MARKOSSIAN S, MALASHICHEVAA, IACONE R, ANASTASSIADIS K, SAVATIER P. (2013). A short G1 phase is an intrinsic determinant of naïve embryonic stem cell pluripotency. Stem Cell Res. 10: 118-131.

COUTEAUDIER M, COURVOISIER K, TRAPP-FRAGNET L, DENESVRE C, VAUTHEROT JF. (2016). Keratinocytes derived from chicken embryonic stem cells support Marek's disease virus infection: a highly differentiated cell model to study viral replication and morphogenesis. Virol J. 13: 7.

COUTEAUDIER M, TRAPP-FRAGNET L, AUGER N, COURVOISIER K, PAIN B, DENESVRE C, VAUTHEROT JF. (2015). Derivation of keratinocytes from chicken embryonic stem cells: establishment and characterization of differentiated proliferative cell populations. Stem Cell Res. 14: 224-237.

DAN J, LI M, YANG J, LI J, OKUKAM, YE X, LIU L. (2013). Roles for Tbx3 in regulation of two-cell state and telomere elongation in mouse ES cells. Sci. Rep. 3: 3492.

DE LOS ANGELES A, FERRARI F, XI R, FUJIWARA Y, BENVENISTY N, DENG H, HOCHEDLINGER K, JAENISCH R, LEE S, LEITCH HG, LENSCH MW, LUJAN E, PEI D, ROSSANT J, WERNIG M, PARK PJ, DALEY GQ. (2015). Hallmarks of pluripotency. Nature. 525: 469-478.

DE WIT, E., BOUWMAN, B.A.M., ZHU, Y., KLOUS, P., SPLINTER, E., VERSTEGEN, M.J.A.M., KRIJGER, P.H.L., FESTUCCIA, N., NORA, E.P., WELLING, M., HEARD, E., GEIJSEN, N., POOT, R.A., CHAMBERS, I. DE LAAT, W. (2013). The pluripotent genome in three dimensions is shaped around pluripotency factors. Nature. 501: 227-231.

DENHOLTZ, M., BONORA, G., CHRONIS, C., SPLINTER, E., DE LAAT, W., ERNST, J., PELLEGRINI, M. and PLATH, K. (2013). Long-range chromatin contacts in embryonic stem cells reveal a role for pluripotency factors and polycomb proteins in genome organization, Cell Stem Cell 13: 602-616.

DUNN SJ, MARTELLO G, YORDANOV B, EMMOTT S, SMITH AG. (2014). Defining an essential transcription factor program for naïve pluripotency. Science. 344 1156-1160

ETCHES RJ, CLARK ME, ZAJCHOWSKI L, SPEKSNIJDER G, VERRINDER GIBBINS AM, KINO K, PAIN B, SAMARUT J. (1997). Manipulation of blastodermal cells. Poult Sci. 76: 1075-1083.

EVANS MJ, KAUFMAN MH. (1981). Establishment in culture of pluripotential cells from mouse embryos. Nature. 292: 154-156.

EVSIKOV AV, DE VRIES WN, PEASTON AE, RADFORD EE, FANCHER KS, CHEN 
FH, BLAKE JA, BULT CJ, LATHAM KE, SOLTER D, KNOWLES BB. (2004). Systems biology of the 2-cell mouse embryo. Cytogenet Genome Res. 105: 240-250.

EXTAVOUR CG, AKAM M. (2003). Mechanisms of germ cell specification across the metazoans: epigenesis and preformation. Development. 130: 5869-5884.

EYAL-GILADI H and KOVAK S. (1976). From cleavage to primitive streak formation: a complementary normal table and a new look at the first stages of the development of the chick. I. General morphology. Dev Biol. 49: 321-37.

FABIAN B, EYAL-GILADI H. (1981). A SEM study of cell shedding during the formation of the area pellucida in the chick embryo. J Embryol Exp Morphol. 64: 11-22.

FRANKENBERG SR, FRANK D, HARLAND R, JOHNSON AD, NICHOLS J, NIWA H, SCHÖLER HR, TANAKA E, WYLIE C, BRICKMAN JM. (2014). The POU-er of gene nomenclature. Development. 141: 2921-2923.

FRANKENBERG SR. (2015). Different Species Choose Their Own Paths to Pluripotency. Dev Cell. 35: 267-268.

FUET AAND PAIN B. (2017). Chicken Induced Pluripotent Stem Cells: Establishment and Characterization. Methods Mol Biol. 1650: 211-228.

FUJII S, NISHIKAWA-TORIKAI S, FUTATSUGI Y, TOYOOKA Y, YAMANE M, OHTSUKA S, NIWA H. (2015). Nrob1 is a negative regulator of Zscan4c in mouse embryonic stem cells. Sci Rep. 5: 9146.

FUSSNER, E., DJURIC, U., STRAUSS, M., HOTTA, A., PEREZ-IRATXETA, C., LANNER, F., DILWORTH, F.J., ELLIS, J. and BAZETT-JONES, D.P. (2011). Constitutive heterochromatin reorganization during somatic cell reprogramming. EMBO J. 30: 1778-1789.

GAFNIO, WEINBERGERL, MANSOURAA, MANORYS, CHOMSKYE, BEN-YOSEF D, KALMA Y, VIUKOV S, MAZA I, ZVIRAN A, RAIS Y, SHIPONY Z, MUKAMEL Z, KRUPALNIK V, ZERBIB M, GEULAS, CASPI I, SCHNEIRD, SHWARTZT, GILAD S, AMANN-ZALCENSTEIN D, BENJAMIN S, AMIT I, TANAY A, MASSARWA R, NOVERSHTERN N, HANNA JH. (2013). Derivation of novel human ground state naive pluripotent stem cells. Nature. 504: 282-286.

GUO G, SMITH A. (2010). A genome-wide screen in EpiSCs identifies Nr5a nuclear receptors as potent inducers of ground state pluripotency. Development. 137: 3185-3192

GUO G, VON MEYENN F, SANTOS F, CHEN Y, REIK W, BERTONE P, SMITH A, NICHOLS J. (2016). Naive Pluripotent Stem Cells Derived Directly from Isolated Cells of the Human Inner Cell Mass. Stem Cell Reports. 6: 437-446.

GUO G, YANG J, NICHOLS J, HALL JS, EYRES I, MANSFIELD W, SMITHA. (2009). Klf4 reverts developmentally programmed restriction of ground state pluripotency. Development. 136: 1063-1069.

HACKETT JA, SURANI MA. (2014). Regulatory principles of pluripotency: from the ground state up. Cell Stem Cell. 15: 416-430.

HACKETT JA, KOBAYASHI T, DIETMANN S, SURANI MA. (2017). Activation of Lineage Regulators and Transposable Elements across a Pluripotent Spectrum. Stem Cell Reports. 8: 1645-1658.

HAHNEL AC, EDDY EM. (1983). Syngeneic antiserum to Nulli SCC1 embryonal carcinoma cells recognizing surface antigens of embryonic cells. $J$ Reprod Immunol. 5: 371-382.

HALLJ, GUO G, WRAY J, EYRES I, NICHOLS J, GROTEWOLD L, MORFOPOULOU S, HUMPHREYS P, MANSFIELD W, WALKER R, TOMLINSON S, SMITH A. (2009). Oct4 and LIF/Stat3 additively induce Krüppel factors to sustain embryonic stem cell self-renewal. Cell Stem Cell. 5: 597-609.

HORIUCHI H, TATEGAKI A, YAMASHITA Y, HISAMATSU H, OGAWA M, NOGUCHI T, AOSASA M, KAWASHIMA T, AKITAS, NISHIMICHI N, MITSUI N, FURUSAWA S, MATSUDA H. (2004). Chicken leukemia inhibitory factor maintains chicken embryonic stem cells in the undifferentiated state. J Biol Chem. 279: 24514-2420.

HWANG YS, KO MH, KIM YM, PARK YH, ONO T, HAN JY. (2016). The avian-specific small heat shock protein HSP25 is a constitutive protector against environmental stresses during blastoderm dormancy. Sci Rep. 6: 36704.

ILLICH DJ, ZHANG M, URSU A, OSORNO R, KIM KP, YOON J, ARAÚZO-BRAVO MJ, WU G, ESCH D, SABOUR D, COLBY D, GRASSME KS, CHEN J, GREBER B, HÖING S, HERZOG W, ZIEGLER S, CHAMBERS I, GAO S, WALDMANN H, SCHÖLER HR. (2016). Distinct Signaling Requirements for the Establishment of ESC Pluripotency in Late-Stage EpiSCs. Cell Rep. S22111247(16)30362-X.

IWAFUCHI-DOI M, YOSHIDA Y, ONICHTCHOUK D, LEICHSENRING M, DRIEVER W, TAKEMOTO T, UCHIKAWA M, KAMACHI Y, KONDOH H. (2011). The Pou5f1/ Pou3f-dependent but SoxBindependent regulation of conserved enhancer N2 initiates Sox2 expression during epiblast to neural plate stages in vertebrates. Dev Biol. 352: 354-366

JEAN C, AUBEL P, SOLEIHAVOUP C, BOUHALLIER F, VOISIN S, LAVIAL F, PAIN B. (2013). Pluripotent genes in avian stem cells. Dev Growth Differ. 55: 41-51.

JEAN C, OLIVEIRA NM, INTARAPAT S, FUET A, MAZOYER C, DE ALMEIDA I, TREVERS K, BOASTS, AUBEL P, BERTOCCHINI F, STERN CD, PAIN B. (2015). Transcriptome analysis of chicken ES, blastodermal and germ cells reveals that chick ES cells are equivalent to mouse ES cells rather than EpiSC. Stem Cell Res. 14: 54-67.

JIAO F., WANG X., YAN Z., LIU C., YUE Z., L, Z., MA Y., LI Y., WANG J. (2013). Effect of dynamic DNA methylation and histone acetylation on cPouV expression in differentiation of chick embryonic germ cells, Stem Cells Dev. 22: 2725-2735.

JIRMANOVAL, AFANASSIEFFM, GOBERT-GOSSES, MARKOSSIANS, SAVATIER P. (2002). Differential contributions of ERK and PI3-kinase to the regulation of cyclin D1 expression and to the control of the G1/S transition in mouse embryonic stem cells. Oncogene.21: 5515-5528.

JORDAN I, JOHN K, HÖWING K, LOHR V, PENZES Z, GUBUCZ-SOMBOR E, FU Y, GAO P, HARDER T, ZÁDORI Z, SANDIG V. (2016). Continuous cell lines from the Muscovy duck as potential replacement for primary cells in the production of avian vaccines. Avian Pathol. 45: 137-155.

JORDANI, VOSA, BEILFUSS S, NEUBERTA, BREULS, SANDIG V. (2009). An avian cell line designed for production of highly attenuated viruses. Vaccine. 27: 748-756.

JURKA J, KAPITONOV VV, PAVLICEK A, KLONOWSKI P, KOHANY O, WALICHIEWICZ J. (2005). Repbase Update, a database of eukaryotic repetitive elements. Cytogenet Genome Res. 110: 462-467.

KALKAN T, OLOVA N, ROODE M, MULAS C, LEE HJ, NETT I, MARKS H, WALKER R, STUNNENBERG HG, LILLEY KS, NICHOLS J, REIK W2, BERTONE P, SMITH A. (2017). Tracking the embryonic stem cell transition from ground state pluripotency. Development. 144: 1221-1234.

KANNAGIR, COCHRANNA, ISHIGAMI F, HAKOMORIS, ANDREWSPW, KNOWLES BB, SOLTER D. (1983). Stage-specific embryonic antigens (SSEA-3 and -4) are epitopes of a unique globo-series ganglioside isolated from human teratocarcinoma cells. EMBO J. 2: 2355-2361.

KARAGIANNIS P, ETO K. (2016). Ten years of induced pluripotency: from basic mechanisms to therapeutic applications. Development. 143: 2039-2043.

KATAYAMA M, HIRAYAMA T, TANI T, NISHIMORI K, ONUMA M, FUKUDA T. (2018). Chick d erived induced pluripotent stem cells by the poly-cistronic transposon with enhanced transcriptional activity. J Cell Physiol. 233: 990-1004.

KAWASAKI H, MIZUSEKI K, NISHIKAWA S, KANEKO S, KUWANA Y, NAKANISHI S, NISHIKAWA SI, SASAI Y. (2000). Induction of midbrain dopaminergic neurons from ES cells by stromal cell-derived inducing activity. Neuron. 28: 31-40.

KIM J, CHU J, SHEN X, WANG J, ORKIN SH. (2009). An extended transcriptional network for pluripotency of embryonic stem cells. Cell. 132: 1049-1061.

KINO K, PAIN B, LEIBO SP, COCHRAN M, CLARK ME, ETCHES RJ. (1997). Production of chicken chimeras from injection of frozen-thawed blastodermal cells. Poult Sci. 76: 753-760.

KRESS C., MONTILLET G., JEAN C., FUET A., PAIN, B. (2016). Chicken embryonic stem cells and primordial germ cells display different heterochromatic histone marks than their mammalian counterparts. Epigenetics Chromatin. 9: 5

LAVIAL F, ACLOQUE H, BACHELARD E, NIETO MA, SAMARUT J, PAIN B. (2009). Ectopic expression of Cvh (Chicken Vasa homologue) mediates the reprogramming of chicken embryonic stem cells to a germ cell fate. Dev Biol. 330: 73-82.

LAVIAL F, ACLOQUE H, BERTOCCHINI F, MACLEOD DJ, BOAST S, BACHELARD E, MONTILLET G, THENOT S, SANG HM, STERN CD, SAMARUT J, PAIN B. (2007). The Oct4 homologue PouV and Nanog regulate pluripotency in chicken embryonic stem cells. Development. 134: 3549-3563.

LAVIAL F, PAIN B. (2010). Chicken embryonic stem cells as a non-mammalian embryonic stem cell model. Dev Growth Differ. 52: 101-114.

LEE HC, CHOI HJ, LEE HG, LIM JM, ONO T, HAN JY. (2016). DAZL Expression Explains Origin and Central Formation of Primordial Germ Cells in Chickens. Stem Cells Dev. 25: 68-79.

LÉON A, DAVID AL, MADELINE 2, GUIANVARC'H L, DUREAU E, CHAMPIONARNAUD P, HEBBEN M, HUSS T, CHATRENET B, SCHWAMBORN K. (2016). The EB66® cell line as a valuable cell substrate for MVA-based vaccines production. Vaccine. 34: 5878-5885 
LERAT E, BIROT AM, SAMARUT J, MEY A. (2007). Maintenance in the chicken genome of the retroviral-like cENS gene family specifically expressed in early embryos. J Mol Evol. 65: 215-227.

LU Y, WEST FD, JORDAN BJ, BECKSTEAD RB, JORDAN ET, STICE SL. (2015). Generation of Avian Induced Pluripotent Stem Cells. Methods Mol Biol. 1330: 89-99.

LUY, WESTFD, JORDANBJ, MUMAW JL, JORDANET, GALLEGOS-CARDENASA BECKSTEAD RB, STICE SL. (2012). Avian-induced pluripotent stem cells derived using human reprogramming factors. Stem Cells Dev.21: 394-403.

MACDONALD J, GLOVER JD, TAYLOR L, SANG HM, MCGREW MJ. (2010). Characterisation and germline transmission of cultured avian primordial germ cells. PLoS One. 5: e15518.

MESHORER E., YELLAJOSHULA D., GEORGE E., SCAMBLER PJ., BROWN DT., MISTELI T. (2006). Hyperdynamic plasticity of chromatin proteins in pluripotent embryonic stem cells, Dev Cell. 10: 105-116.

MACFARLANTS, GIFFORDWD, DRISCOLLS, LETTIERIK, ROWE HM, BONANOMI D, FIRTH A, SINGER O, TRONO D, PFAFF SL. (2012). Embryonic stem cell potency fluctuates with endogenous retrovirus activity. Nature. 487: 57-63.

MAK SS, ALEV C, NAGAI H, WRABEL A, MATSUOKA Y, HONDA A, SHENG G, LADHER RK. (2015). Characterization of the finch embryo supports evolutionary conservation of the naive stage of development in amniotes. Elife. 4: e07178.

MARKS H, KALKAN T, MENAFRA R, DENISSOV S, JONES K, HOFEMEISTER H, NICHOLS J, KRANZ A, STEWART AF, SMITH A, STUNNENBERG HG. (2012). The transcriptional and epigenomic foundations of ground state pluripotency. Cell. 149: 590-604.

MARTIN GR. (1981). Isolation of a pluripotent cell line from early mouse embryos cultured in medium conditioned by teratocarcinoma stem cells. Proc Natl Acad Sci USA. 78: 7634-7638.

MASLOVA A., ZLOTINA A., KOSYAKOVA N., SIDOROVA M. and KRASIKOVA A (2015). Three-dimensional architecture of tandem repeats in chicken interphase nucleus. Chromosome Res. 23: 625-639.

MASON AS, FULTON JE, HOCKING PM, BURT DW. (2016). A new look at the LTR retrotransposon content of the chicken genome. BMC Genomics.17: 688.

MATTOUTA., MESHORER E. (2010). Chromatin plasticity and genome organization in pluripotent embryonic stem cells. Curr Opin Cell Biol. 22: 334-341.

MEY A, ACLOQUE H, LERAT E, GOUNEL S, TRIBOLLET V, BLANC S, CURTON D, BIROT AM, NIETO MA, SAMARUT J. (2012). The endogenous retrovirus ENS-1 provides active binding sites for transcription factors in embryonic stem cells that specify extra embryonic tissue. Retrovirology. 9: 21.

MURRAY JR, VARIAN-RAMOS CW, WELCH ZS, SAHA MS. (2013). Embryological staging of the Zebra Finch, Taeniopygia guttata. J Morphol. 274: 1090-1110.

NAGAI H, SEZAKI M, KAKIGUCHI K, NAKAYA Y, LEE HC, LADHER R, SASANAMI T, HAN JY, YONEMURAS, SHENG G. (2015). Cellular analysis of cleavage-stage chick embryos reveals hidden conservation in vertebrate early development. Development. 142: 1279-1286.

NAKANOH S, FUSE N, TADOKORO R, TAKAHASHI Y, AGATA K. (2017). Jak1/ Stat3 signaling acts as a positive regulator of pluripotency in chicken pre-gastrula embryos. Dev Biol. 421: 43-51.

NAKANOH S, FUSE N, TAKAHASHI Y, AGATA K. (2015). Verification of chicken Nanog as an epiblast marker and identification of chicken PouV as Pou5f3 by newly raised antibodies. Dev Growth Differ. 57: 251-263.

NARUSE T, FUKUDA T, TANABE T, ICHIKAWA M, ODA Y, TOCHIHARA S, KIMACH K, KINO Y, UEDA K. (2015). A clinical phase I study of an EB66 cell-derived H5N1 pandemic vaccine adjuvanted with AS03. Vaccine 33: 6078-6084.

NICHOLS J, SILVA J, ROODE M, SMITH A. (2009). Suppression of Erk signalling promotes ground state pluripotency in the mouse embryo. Development. 136: 3215-3222.

NICHOLS J, SMITH A. (2009). Naive and primed pluripotent states. Cell Stem Cell. 4: 487-492.

ORKIN S.H. and HOCHEDLINGER K. (2011). Chromatin connections to pluripotency and cellular reprogramming. Cell 145: 835-850.

PAIN B, CLARK ME, SHEN M, NAKAZAWA H, SAKURAI M, SAMARUT J, ETCHES RJ. (1996). Long-term in vitroculture and characterisation of avian embryonic stem cells with multiple morphogenetic potentialities. Development. 122: 2339-2348.

PANDA RP, BARMAN HK, MOHAPATRA C. (2011). Isolation of enriched carp spermatogonial stem cells from Labeo rohita testis for in vitro propagation.
Theriogenology 76: 241-51

PAPANAYOTOU C, MEY A, BIROT AM, SAKA Y, BOAST S, SMITH JC, SAMARUT J, STERN CD. (2008). A mechanism regulating the onset of Sox2 expression in the embryonic neural plate. PLoS Biol. 6: e2.

PEASTONAE, EVSIKOVAV, GRABER JH, DE VRIES WN, HOLBROOKAE, SOLTER D, KNOWLESBB. (2004). Retrotransposons regulate host genes in mouse oocytes and preimplantation embryos. Dev Cell. 7: 597-606.

PEDERSEN M.T., KOOISTRA S.M., RADZISHEUSKAYA A., LAUGESEN A., JOHANSEN J.V., HAYWARD D.G., NILSSON J., AGGER K. and HELIN K. (2016). Continual removal of $\mathrm{H} 3 \mathrm{~K} 9$ promoter methylation by Jmjd2 demethylases is vita for ESC self-renewal and early development. EMBO J. 35: 1550-1564.

PETELL C.J., ALABDI L., HE M., SAN MIGUEL P., ROSE R., GOWHER H. (2016) An epigenetic switch regulates de novo DNA methylation at a subset of pluripotency gene enhancers during embryonic stem cell differentiation Nucleic Acids Res. 44: 7605-7617.

PETIOT E, PROUST A, TRAVERSIER A, DUROUS L, DAPPOZZE F, GRAS M, GUILLARD C, BALLOUL JM, ROSA-CALATRAVA M. (2017). Influenza viruses production: Evaluation of a novel avian cell line DuckCelt@-T17. Vaccine. S0264410X: 30502-30509.

PETITTE JN, CLARK ME, LIU G, VERRINDER GIBBINS AM, ETCHES RJ. (1990) Production of somatic and germline chimeras in the chicken by transfer of early blastodermal cells. Development. 108: 185-189.

PETITTE JN, LIU G, YANG Z. (2004). Avian pluripotent stem cells. Mech Dev. 121: 1159-1168.

RENGARAJ D, LEE BR, LEE SI, SEO HW, HAN JY. (2011). Expression patterns and miRNA regulation of DNA methyltransferases in chicken primordial germ cells. PLoS One. 6: e19524.

REX M, ORME A, UWANOGHO D, TOINTON K, WIGMORE PM, SHARPE PT, SCOTTING PJ. (1997). Dynamic expression of chicken Sox2 and Sox3 genes in ectoderm induced to form neural tissue. Dev Dyn. 209: 323-332.

ROELLIG D, TAN-CABUGAO J, ESAIAN S, BRONNER ME. (2017). Dynamic transcriptional signature and cell fate analysis reveals plasticity of individual neural plate border cells. Elife. 6: e21620.

ROSSELLÓ RA, CHEN CC, DAIR, HOWARDJT, HOCHGESCHWENDERU, JARVIS ED. (2013). Mammalian genes induce partially reprogrammed pluripotent stem cells in non-mammalian vertebrate and invertebrate species. Elife. 2: e00036.

ROWE HM, JAKOBSSON J, MESNARD D, ROUGEMONT J, REYNARD S, AKTAS T, MAILLARD PV, LAYARD-LIESCHING H, VERP S, MARQUIS J, SPITZ F, CONSTAM DB, TRONO D. (2010). KAP1 controls endogenous retroviruses in embryonic stem cells. Nature. 463: 237-240.

SASADO T, KANI S, WASHIMI K, OZATO K, WAKAMATSU Y. (1999). Expression of murine early embryonic antigens, SSEA-1 and antigenic determinant of EMA1 , in embryos and ovarian follicles of a teleost medaka (Oryzias latipes). Dev Growth Differ. 41: 293-302.

SAVATIER P, OSTEIL P, TAM PP. (2017). Pluripotency of embryo-derived stem cells from rodents, lagomorphs, and primates: Slippery slope, terrace and cliff. Stem Cell Res. 19: 104-112.

SELLIER N., BRILLARD JP., DUPUY V., BAKST MR. (2006). Comparative Staging of Embryo Development in Chicken, Turkey, Duck, Goose, Guinea Fowl, and Japanese Quail Assessed from Five Hours After Fertilization Through SeventyTwo Hours of Incubation. J Appl Poult Res 15: 219-228.

SHENG G. (2014). Day-1 chick development. Dev Dyn. 243: 357-367.

SHIN M, ALEV C, WU Y, NAGAI H, SHENG G. (2011). Activin/TGF-beta signaling regulates Nanog expression in the epiblast during gastrulation. Mech Dev. 128: 268-278.

SMITH A. (2017). Formative pluripotency: the executive phase in a developmental continuum. Development. 144: 365-373.

SOLTER D, KNOWLES BB. (1978). Monoclonal antibody defining a stage-specific mouse embryonic antigen (SSEA-1). Proc Natl Acad Sci USA. 75: 5565-5569.

SOLTER D, HIIRAGI T, EVSIKOV AV, MOYER J, DE VRIES WN, PEASTON AE, KNOWLESBB. (2004). Epigenetic mechanisms in early mammalian development. Cold Spring Harb Symp Quant Biol. 2004; 69: 11-17.

STADTFELD M, HOCHEDLINGER K. (2010). Induced pluripotency: history, mechanisms, and applications. Genes Dev. 24: 2239-2263.

STREITA1, BERLINERAJ, PAPANAYOTOU C, SIRULNIKA, STERNCD. (2000). Initia- 
tion of neural induction by FGF signalling before gastrulation. Nature. 406: 74-78.

TAKAHASHI K, YAMANAKAS. (2006). Induction of pluripotent stem cells from mouse embryonic and adult fibroblast cultures by defined factors. Cell. 126: 663-676.

TAKAHASHI K, YAMANAKA S. (2016). A decade of transcription factor-mediated reprogramming to pluripotency. Nat Rev Mol Cell Biol. 17: 183-193.

TAKASHIMA Y, GUO G, LOOS R, NICHOLS J, FICZ G, KRUEGER F, OXLEY D, SANTOS F, CLARKE J, MANSFIELD W, REIK W, BERTONE P, SMITHA. (2014). Resetting transcription factor control circuitry toward ground-state pluripotency in human. Cell 158: 1254-1269.

TESAR PJ, CHENOWETH JG, BROOK FA, DAVIES TJ, EVANS EP, MACK DL, GARDNER RL, MCKAY RD. (2007). New cell lines from mouse epiblast share defining features with human embryonic stem cells. Nature. 448: 196-199.

THEUNISSEN TW, FRIEDLI M, HE Y, PLANET E, O'NEIL RC, MARKOULAKI S, PONTIS J, WANG H, IOURANOVAA, IMBEAULT M, DUC J, COHEN MA, WERT KJ, CASTANON R, ZHANG Z, HUANG Y, NERY JR, DROTAR J, LUNGJANGWA T, TRONO D, ECKER JR, JAENISCH R. (2016). Molecular Criteria for Defining the Naive Human Pluripotent State. Cell Stem Cell. 19: 502-515.

THEUNISSENTW, POWELLBE, WANG H, MITALIPOVAM, FADDAHDA, REDDY J, FANZP, MAETZELD, GANZK, SHIL, LUNGJANGWAT, IMSOONTHORNRUKSA S, STELZER Y, RANGARAJAN S, D'ALESSIO A, ZHANG J, GAO Q, DAWLATY MM, YOUNG RA, GRAY NS, JAENISCH R. (2014). Systematic identification of culture conditions for induction and maintenance of naive human pluripotency. Cell Stem Cell. 15: 471-487.

THOMSON JA, ITSKOVITZ-ELDOR J, SHAPIRO SS, WAKNITZ MA, SWIERGIEL JJ, MARSHALL VS, JONES JM. (1998). Embryonic stem cell lines derived from human blastocysts. Science. 282: 1145-1147.

THOMSON JA, KALISHMAN J., GOLOS TG., DURNING M., HARRIS CP., BECKER RA., HEARN JP. (1995). Isolation of a primate embryonic stem cell line. Proc Natl Acad Sci USA. 92: 7844-7848.

TOLLERVEY J.R., LUNYAK V.V. (2012). Epigenetics: Judge, jury and executioner of stem cell fate. Epigenetics. 7: 823-840.

TSUNEKAWAN, NAITO M, SAKAIY, NISHIDAT, NOCE T. (2000). Isolation of chicken vasa homolog gene and tracing the origin of primordial germ cells. Development. 127: 2741-2750.

URVEN LE, ERICKSON CA, ABBOTT UK, MCCARREY JR. (1988). Analysis of germ line development in the chick embryo using an anti-mouse EC cell antibody. Development 103: 299-304.

VAN DE LAVOIR MC, DIAMOND JH, LEIGHTON PA, MATHER-LOVE C, HEYER BS, BRADSHAW R, KERCHNER A, HOOI LT, GESSARO TM, SWANBERG SE, DELANY ME, ETCHES RJ. (2006). Germline transmission of genetically modified primordial germ cells. Nature. 441: 766-769.

VAN DE LAVOIR MC, MATHER-LOVE C, LEIGHTON P, DIAMOND JH, HEYER BS, ROBERTS R, ZHU L, WINTERS-DIGIACINTO P, KERCHNER A, GESSARO T, SWANBERG S, DELANY ME, ETCHES RJ. (2006). High-grade transgenic somatic chimeras from chicken embryonic stem cells. Mech Dev. 123: 31-41.

VAUTHEROT JF, JEAN C, FRAGNET-TRAPP L, RÉMYS, CHABANNE-VAUTHEROT D, MONTILLET G, FUET A, DENESVRE C, PAIN B. (2017). ESCDL-1, a new cell line derived from chicken embryonic stem cells, supports efficient replication of Mardiviruses. PLoS One. 12: e0175259.

VOIGT P., TEE W., REINBERG D. (2013). A double take on bivalent promoters. Genes Dev., 27: 1318-1338.

WANG X., WANG Y., ZUO Q., LI D., ZHANG W., LIAN C., TANG B., XIAO T., WANG M., WANG K., LI B. ZHANG Y. (2016). The synergistic effect of 5Azadc and TSA on maintenance of pluripotency of chicken ESCs by overexpression of NANOG gene, In Vitro Cell. Dev. Biol. Animal, 52: 488-496.

WARE CB. (2016). Concise Review: Lessons from Naïve Human Pluripotent Cells. Stem Cells. 35: 35-41.

WATT JM, PETITTE JN, ETCHES RJ. (1993). Early development of the chick embryo J Morphol. 215: 165-182.

WHYTEJ, GLOVERJD, WOODCOCKM, BRZESZCZYNSKAJ, TAYLORL, SHERMAN A, KAISERP, MCGREW MJ. (2015). FGF, Insulin, and SMAD Signaling Cooperate for Avian Primordial Germ Cell Self-Renewal. Stem Cell Reports.5: 1171-1182.

YING QL, WRAY J, NICHOLS J, BATLLE-MORERA L, DOBLE B, WOODGETT J, COHENP, SMITHA. (2008). The ground state of embryonic stem cell self-renewal. Nature. 453: 519-523.

YOSHIDA-NORO C, HEASMAN J, GOLDSTONE K, VICKERS L, WYLIE C. (1999). Expression of the Lewis group carbohydrate antigens during Xenopus development. Glycobiology 9: 1323-1330.

YU J, VODYANIK MA, SMUGA-OTTO K, ANTOSIEWICZ-BOURGET J, FRANE JL, TIAN S, NIE J, JONSDOTTIR GA, RUOTTI V, STEWART R, SLUKVIN II, THOMSON JA. (2007); Induced pluripotent stem cell lines derived from human somatic cells. Science 318: 1917-1920.

YU P, LU Y, JORDAN BJ, LIU Y, YANG JY, HUTCHESON JM, ETHRIDGE CL, MUMAW JL, KINDER HA, BECKSTEAD RB, STICE SL, WEST FD. (2014). Nonviral minicircle generation of induced pluripotent stem cells compatible with production of chimeric chickens. Cell Reprogram. 16: 366-378.

ZHOU H, LI W, ZHU S, JOO JY, DO JT, XIONG W, KIM JB, ZHANG K, SCHÖLER HR DING S. (2010). Conversion of mouse epiblast stem cells to an earlier pluripotency state by small molecules. J Biol Chem. 285: 29676-29680. 


\section{Further Related Reading, published previously in the Int. J. Dev. Biol.}

Teratomas produced from human pluripotent stem cells xenografted into immunodeficient mice - a histopathology atlas Ivan Damjanov and Peter W. Andrews

Int. J. Dev. Biol. (2016) 60: 337-419

https://doi.org/10.1387/ijdb.160274id

Comparative epigenetic evaluation of human embryonic stem and induced pluripotent cells

Raha Favaedi, Maryam Shahhoseini, Mahammad Pakzad, Sepideh Mollamohammadi and Hossein Baharvand

Int. J. Dev. Biol. (2016) 60: 103-110

https://doi.org/10.1387/ijdb.140332ms

The Oct4 promoter-EGFP transgenic rabbit: a new model for monitoring the pluripotency of rabbit stem cells

Mingru Yin, Zhenfu Fang, Weihua Jiang, Fengying Xing, Manxi Jiang, Pengcheng Kong, Yao Li, Xiaomei Zhou, Lan Tang, Shangang Li and Xuejin Chen

Int. J. Dev. Biol. (2013) 57: 845-852

https://doi.org/10.1387/ijdb.130128sl

Signaling pathways dictating pluripotency in embryonic stem cells

Debasree Dutta

Int. J. Dev. Biol. (2013) 57: 667-675

https://doi.org/10.1387/ijdb.130064dd

Testicular teratomas: an intersection of pluripotency, differentiation and cancer biology Ximena Bustamante-Marín, Jason A. Garness and Blanche Capel

Int. J. Dev. Biol. (2013) 57: 201-210

https://doi.org/10.1387/ijdb.130136bc

Male germ cells and cancer: a connection among pluripotency, differentiation and stem cell biology

Massimo De Felici and Susanna Dolci

Int. J. Dev. Biol. (2013) 57: 101-103

https://doi.org/10.1387/ijdb.130167md

Hydractinia, a pioneering model for stem cell biology and reprogramming somatic cells to pluripotency

Günter Plickert, Uri Frank and Werner A. Müller

Int. J. Dev. Biol. (2012) 56: 519-534

https://doi.org/10.1387/ijdb.123502gp

5 yr ISI Impact Factor $(2016)=2.421$
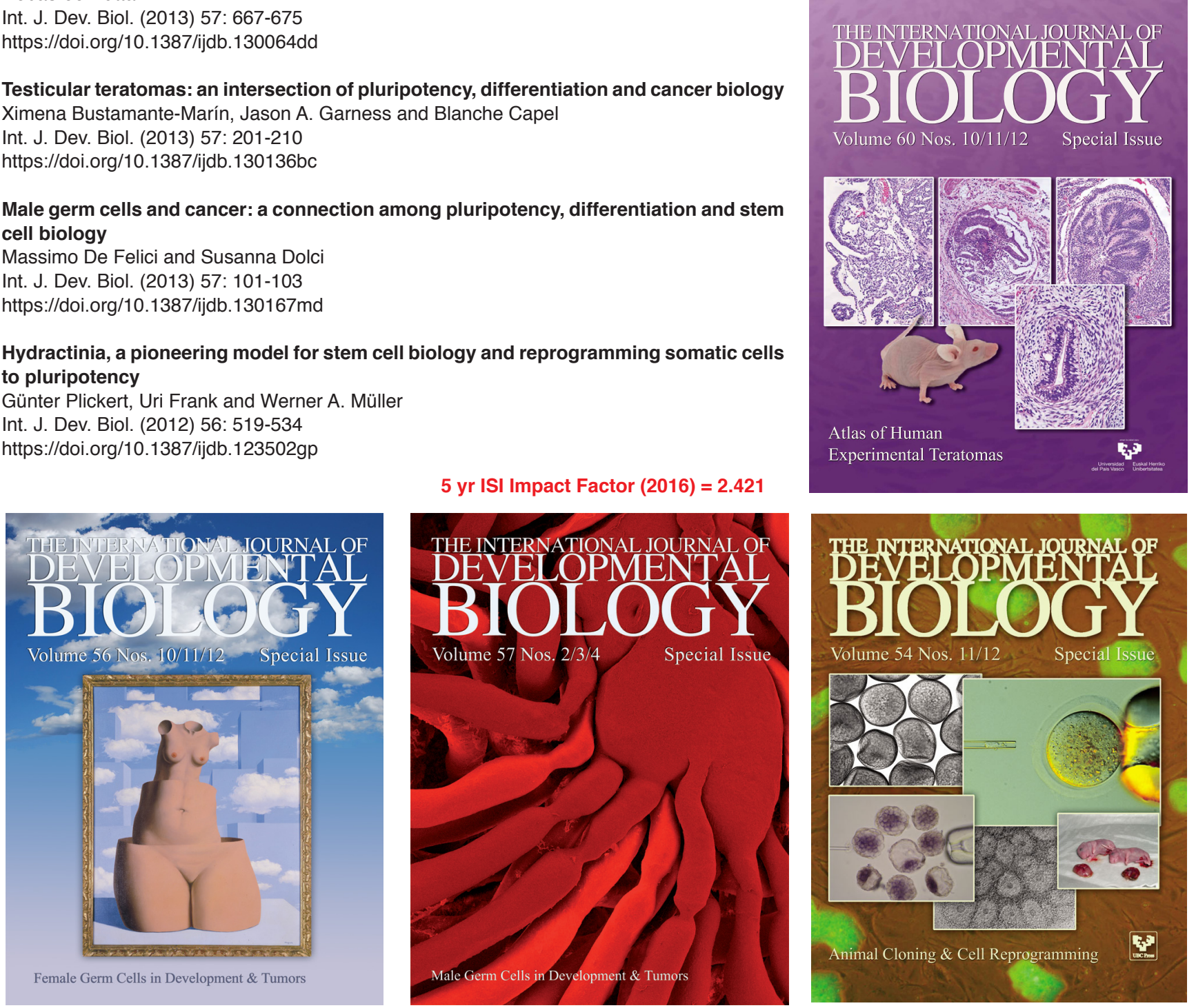